\title{
Establishing a job-crafting and intrapreneurial link: Towards new approaches to innovative work
}

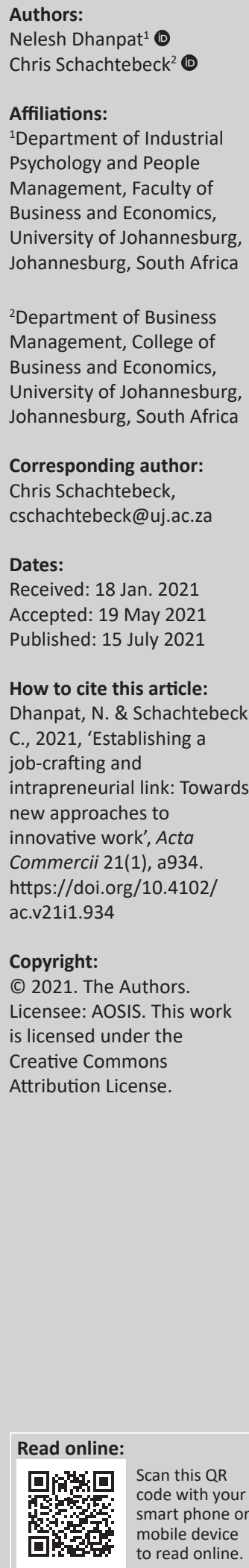

Orientation: This research study focuses on establishing a link between job crafting and landmark studies on intrapreneurship.

Research purpose: The purpose of this study was to provide a theoretical overview of intrapreneurship, intrapreneurial orientation and job crafting, and to explore theoretical linkages between these areas of enquiry.

Motivation for the study: There is currently a dearth of research studies that explore the link between job crafting and intrapreneurial behaviours in existing organisations in the form of intrapreneurial orientation.

Research design, approach and method: The study is presented as a conceptual paper in the form of a qualitative, theoretical study, employing a model-building approach. A deductive research approach is followed, and a narrative review methodology is employed.

Main findings: The findings of this study from a literature search acknowledge the contributions of job crafting and intrapreneurial research within the management sciences, and we remain cognisant of the organisational implications of each, which have, to date, focused on the organisation, rather than the individual. With this in mind, we suggest that job crafting and intrapreneurial behaviours are empirically researched to validate the recommendations made.

Practical/managerial implications: This study will help to establish the type of job-crafting interventions and job-crafting strategies needed to promote intrapreneurial behaviours in practice.

Contribution/value-add: This study provides noteworthy insights, which include the suggestion that employees with a forward-looking disposition will engage in job crafting, with a focus on intrapreneurial behaviour. Furthermore, the study fills a void left in the current body of knowledge.

Keywords: job crafting; entrepreneurship; intrapreneurship; work engagement; innovation.

\section{Introduction}

Competition in the modern economy can be difficult for small- and medium-sized enterprises (SMEs), as well as large enterprises - for some, because of resource limitations, thereby compelling businesses to establish new ways of innovation and competition (Mafini, Pooe \& Loury-Okoumba 2016; Rahayu \& Day 2015; Van Niekerk 2014). It is generally accepted that SMEs are characterised as creators and the drivers of innovation; however, large corporates in the face of new competitive threats will often re-examine their competitive positioning in an effort to adapt to current market changes (Van Wyk \& Adonisi 2012). Several studies (e.g. Drotskie \& Okanga 2016; Strydom 2013) have suggested that businesses need to possess certain internal elements in order to accelerate growth, most prominently elements of innovation, internal competencies, internal leadership, risk-taking capabilities and managerial support. Mxunyelwa and Vallabh (2017) accordingly argued that entrenching a culture of entrepreneurship is deeply beneficial when seeking to establish and strengthen internal capabilities, such as risk-taking competencies, creativity and innovation. It is to this effect that the role of the so-called 'intrapreneur' has been acknowledged as important in countering stagnation, overcoming internal hurdles to acting entrepreneurially and ultimately, entrenching innovation (Azami 2013). However, implementation of the intrapreneurship agenda in existing organisations has been largely neglected, with a sustained focus on survival strategies, resulting in depressed internal growth prospects (Badenhorst-Weiss \& Cilliers 2014; Okanga \& Drotskie 2016). This can also partly be attributed to a phenomenon that Neneh and Van Zyl (2014) term a lack of 'internal opportunity obsession'. Some authors in the 
field of intrapreneurship, such as Bolton (2012) and Bolton and Lane (2012), have praised the creation of an 'intrapreneurial orientation' as positively affecting the performance of an organisation. Viewed simplistically, an intrapreneurial orientation (IO) can be seen as current employees exhibiting entrepreneurial traits in an existing organisation. From an organisation-wide perspective, a multitude of studies have confirmed a direct and positive relationship between an organisation's entrepreneurial orientation (EO), corporate entrepreneurship (CE) and organisational performance (Antončič \& Hisrich 2004; Zahra 1991, 1993; Zahra \& Covin 1995), thereby highlighting the beneficial role entrepreneurial traits and actions have for established organisations.

\section{Purpose of the study}

As this study is presented in the form of a conceptual paper, the purpose of this study was to provide a theoretical overview of intrapreneurship, IO and job crafting, and to explore theoretical linkages between these areas of enquiry. By highlighting theoretical linkages between these concepts, managerial implications can be made to propose innovative work implementation measures by employing job-crafting and IO principles. As the concept of IO has its conceptual roots in EO, this concept will also be explored. In this study, it is proposed that intrapreneurs can benefit from engaging in job-crafting activities, namely, through proactively altering one's job tasks, duties or relationships (Wrzesniewski \& Dutton 2001). From a practical and theoretical point of view, it is essential that we understand the effects of job crafting on employee well-being and the performance of employees (Boehnlein \& Baum 2020; Tims, Bakker \& Derks 2015). Hence, there is a need for organisations to remain cognisant of the factors that promote job-crafting behaviours of intrapreneurs. There is currently a dearth of research studies that provide insights into linking job crafting to intrapreneurial behaviours and outcomes.

\section{Literature review}

The following literature review unpacks the theoretical underpinnings of $\mathrm{EO}, \mathrm{IO}$ and job crafting, with a focus on theoretical linkages.

\section{Entrepreneurial orientation}

Viewed from an organisation-wide perspective, EO manifests itself as an enterprise that acts in an entrepreneurial manner. Miller (1983:771) described an entrepreneurial enterprise as 'one that engages in product-market innovation, undertakes somewhat risky ventures, and is first to come up with "proactive" innovations, beating competitors to the punch". Avlonitis and Salavou (2007:567) aptly summarised the longheld perceptions of EO, defining it as 'a firm-level disposition to engage in behaviours (risk taking, innovativeness, proactiveness and aggressiveness) that lead to change in the organisation or marketplace'. Whilst the traditional view of $\mathrm{EO}$ is that it manifests itself throughout the whole organisation, a further notion has been deliberated in the literature, questioning whether EO could manifest itself as a business-unit-level phenomenon or whether it can manifest itself in a single business unit in a multi-business enterprise. Covin and Lumpkin (2011) argued that EO in a certain business unit cannot and should not be extrapolated to the entire organisation. This view gives credence to the notion that EO is essentially a behavioural concept manifested by agility, situational alertness and proactive adaptiveness that goes beyond structure (Mishra 2017). Entrepreneurial Orientation is usually characterised by three to five dimensions (some of which have been mentioned previously in this paper). The three most widely used dimensions include (1) proactiveness, (2) innovativeness and (3) risk taking, in line with Miller's (1983) original conceptualisation. Based on this notion, several prominent authors have claimed that EO is unidimensional, with all three dimensions having to be present for an EO to exist (Covin \& Slevin 1989; Knight 1997; Rauch et al. 2009). In a landmark study, Lumpkin and Dess (1996) refuted this notion by arguing that EO is multidimensional in nature and is more accurately measured by the addition of two dimensions to the EO construct: (4) autonomy and (5) competitive aggressiveness. Autonomy is defined as an individual or team effort that brings an idea to life, whilst meeting the desire of an employee to craft ideas and pursue opportunities with a high level of freedom $(\mathrm{Li}$, Huang \& Tsai 2009; Lumpkin \& Dess 1996). Competitive aggressiveness makes reference to the manner in which competitors are challenged in the marketplace, through either the modification or introduction of new products, processes or activities to the marketplace (Jacobs \& Kruger 2001; Lumpkin \& Dess 1996; Teles \& Schachtebeck 2019). In terms of the Miller's original three dimensions, innovativeness in the entrepreneurial context is an individual's tendency to seek out and experiment with new ideas to bring about competitive advantage, whilst at an organisational level it is a tendency to support new ideas and associated results (Covin \& Miles 1999; Lumpkin \& Dess 1996). Risk taking is closely associated with innovation as any introduction of new product or technology holds inherent risks (Miller 1983), which bring with them uncertainty of outcomes and the possibility of loss (Blundel \& Lockett 2011; Morris \& Kuratko 2002). Proactiveness is the hunt for competitive advantage by being adaptable to changes in the environment, which is of utmost importance for intrapreneurship as it requires forward-looking entrepreneurial action throughout the organisation (Urban 2011, 2012).

In the existing body of knowledge, the focus has primarily been to measure EO at an organisational level. However, in recent years, a school of thought has emerged, which believes that $\mathrm{EO}$ at an individual level has been neglected, as it is the individual employee who ultimately identifies opportunities and acts in an entrepreneurial manner to pursue the opportunity. Studies have also revealed that individual differences amongst employees contribute towards the displayed level of EO (Kollmann, Christofor \& Kuckertz 2007; Quaye, Acheampong \& Asiedu 2015). This study, therefore, acknowledges the conceptual roots of EO from an organisation- 
wide perspective, as the conceptual underpinnings of IO lie in EO, whilst stressing that internal environmental elements, such as structure, policies and management style, have an effect on the individual employee and on his or her ability to innovate and structure their work.

\section{Intrapreneurial orientation}

Whilst the idea of entrepreneurial behaviours exhibited by existing employees has been in circulation for many decades in the form of 'corporate entrepreneurship' (Van Aardt \& Bezuidenhout 2017), these are normally also pegged at the organisational level, with prominent authors, such as Morris, Kuratko and Covin (2008), explaining that CE can take forms of 'strategic entrepreneurship' or 'corporate venturing'. Corporate venturing is mainly associated with the creation of a new business, such as a spin-off venture, whilst strategic entrepreneurship is internal to an organisation and has the outcome of reinvigorating strategic posture. As the term 'corporate entrepreneurship', by virtue of its very name, is associated with large businesses, there has been a growing appreciation for entrepreneurial behaviours by existing employees within organisations of any size. This has led to the emergence of the term 'intrapreneurship'. Antončič and Hisrich (2003:20) aptly summarised this growing appreciation by stating that 'intrapreneurship is an essentially activitybased or activity-oriented concept that operates at the organizational boundary and stretches (the organization) in new directions'. The key to intrapreneurship includes emergent behavioural intentions and, in particular, behaviours towards work that are usually associated with a departure from the customary (Antončič \& Hisrich 2003; Antončič \& Scarlat 2005). Antončič and Scarlat (2005:72) summarised these sought-after behaviours as 'new business venturing, product/service innovation, process innovation, self-renewal, risk taking, proactiveness, and competitive aggressiveness'.

The benefits of employees exhibiting intrapreneurial behaviours have been widely acknowledged, with the creation of an opportunity-seeking mindset amongst employees, resulting in the discovery of emergent opportunities in the marketplace, as well as in development and implementation of rapid and creative solution (Kocjančič \& Bojnec 2013). Apart from the benefits stemming from the central purpose of intrapreneurial behaviours, such as higher levels of innovation, proactiveness, risk taking, strategic renewal and creation of spin-off ventures, other authors have found a link between these sought-after behaviours and growth or profitability, regardless of the size of the organisation (Antončič \& Hisrich 2004; Covin \& Slevin 1986; Schachtebeck 2018; Zahra 1991, 1993).

Several other studies have confirmed other benefits associated with employee-led intrapreneurial behaviours, such as increased levels of competitive advantage, sustainability and profitability (Groenewald \& Van Vuuren 2011; Ireland, Covin \& Kuratko 2009). The primary benefits of intrapreneurial behaviours and their direct effects are summarised in Figure 1.

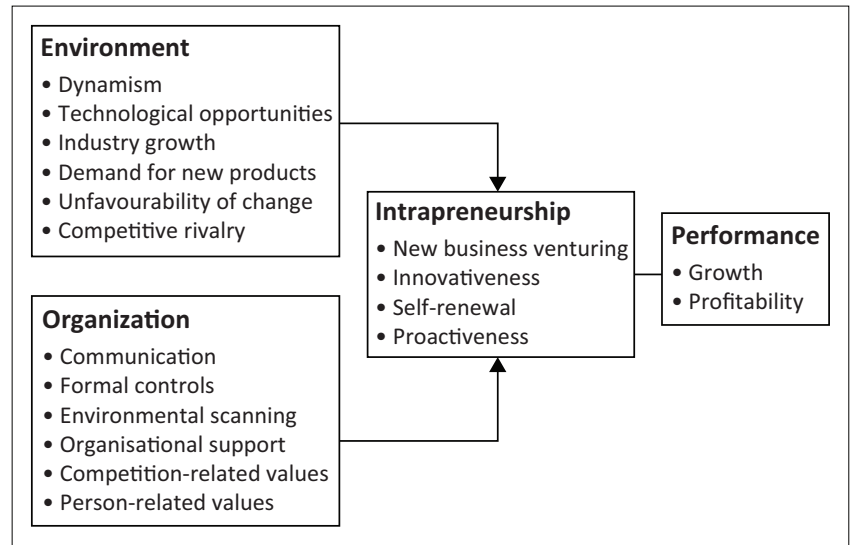

Source: Antončič, B. \& Hisrich, R.D., 2001, 'Intrapreneurship: Construct refinement and cross-cultural validation', Journal of Business Venturing 16(5), 505. https://doi.org/10.1016/ S0883-9026(99)00054-3

FIGURE 1: The intrapreneurship model and its direct effects.

In a previous study (Dhanpat \& Schachtebeck 2019), aiming to link the concepts of CE or intrapreneurship and work engagement, we proposed the inclusion of work engagement as a positive moderating factor between intrapreneurial behaviours in an organisation and organisational performance, notably in growth and profitability measures. Kelly (2011) confirmed that the implementation of CE or intrapreneurship is dependent on employees who are engaged in their work. This, therefore, also takes job-crafting aspects into account.

Intrapreneurial orientation can be viewed as an entrepreneurial mindset shared by employees in an organisation (Lyon, Lumpkin \& Dess 2000). An IO can also be defined as 'an individual employee's predisposition to accept entrepreneurial processes, practices and decision-making characterised by a preference for innovativeness, risk-taking and proactiveness' (Stewart 2009:29). Intrapreneurial orientation was initially conceptualised from the body of knowledge on EO because of certain conceptual shortcomings (Bolton \& Lane 2012). These shortcomings include a sustained focus on EO in the literature at an organisational level, most prominently at the strategic and project level, thereby ignoring aspects concerning the individual employee. Belousova, Gailly and Basso (2010) affirmed that there is merit in an investigation into entrepreneurial behaviour at an individual level in an organisation, as well as the forces driving this behaviour. Camelo-Ordaz et al. (2011:514) described individuals within an organisation who exhibit entrepreneurial behaviour as 'architects, supporters and developers of the firm's creative capabilities'.

Whilst the focus in the literature has predominantly been on the concept of EO, in which IO has its roots, the two concepts are fundamentally different, even though there is some commonality in their outcomes. EO is pegged at the organisational level and seen as a 'strategy-making process that provides organisations with a basis for $\mathrm{EO}$ and actions' (Rauch et al. 2009:762). In contrast, the body of knowledge underpinning the IO concept accepts the merits behind entrepreneurial behaviours driven by strategy and policy but calls for an investigation at the individual level, that is, by 
examining the traits of each employee. Authors, such as Azami (2013), described internal entrepreneurs as those employees who demonstrate pertinent traits, including elements of proactiveness, patience, perseverance, risk taking and creativity. The seminal work of Miller (1983) describes the traits an organisational entrepreneur usually exhibits as those associated with innovativeness, proactiveness and risk taking. Building on the works of Miller, Pinchot (1985) coined the term 'intrapreneuring', thereby giving credence to the identification of entrepreneurial traits of the internal entrepreneur. At an organisational level, hallmark studies have confirmed three traits - innovativeness, risk taking and proactiveness - as comprising the main dimensions of EO (Covin \& Slevin 1991, 1997; Lumpkin \& Dess 1996). Whilst these three dimensions of $\mathrm{EO}$ have been accepted in the literature, it was Lumpkin and Dess $(1996,2005)$ who argued that Miller's original three dimensions can be extended to five through the inclusion of autonomy and competitive aggressiveness.

Authors, such as Lumpkin and Dess (1996), as well as Matsuno, Mentzer and Özsomer (2002), found that the five dimensions of $\mathrm{EO}$ are equally applicable to $\mathrm{IO}$, albeit focused on the individual employee. This view is supported by other authors, including Aarakit and Kimbugwe (2015) and Griffith, Noble and Qimei (2006), with Aarakit (2010) having found that $59.75 \%$ of IO capacity is attributable to innovation, risk taking and proactiveness at the individual level. Effective implementation and encouragement of IO are essentially dependent on internal acceptance and encouragement of certain behaviours, most prominently the aforementioned three dimensions. It should, however, be borne in mind that these dimensions are context bound and differ because of a variety of factors, which can be macro-environmental, such as industry, or micro-environmental, such as organisational structure, size and available resource base (Antončič 2003; Dess \& Lumpkin 2005; Lumpkin \& Dess 1996).

Innovativeness at the individual level, as a dimension of $\mathrm{IO}$, is aptly summarised by Aarakit (2010), who states that:

[C] ustomers are increasingly requiring unique, personalized products and sales solutions. In fact, one of the most widely shared characteristics among successful employees is the adoption of an innovative, creative work approach. (pp. 44-45)

\section{Job crafting}

A well-designed job requires sufficient resources and challenging demands. Organisational scholars look towards job design in fostering work that promotes well-being, motivation and performance (Oldham \& Hackman 2010). As such, Schulte and Vainio (2010) maintained that a healthy workforce is essential for sustaining effectiveness and promoting innovation. Traditionally, job design was characterised by a top-down approach that included actions undertaken by the organisation to enhance an individual's motivation and overall performance of the organisation (Tims \& Bakker 2010; Weseler \& Niessen 2016). Changes, such as varying work patterns and work arrangements, have led to a new perspective of job redesign with more focus on proactivity (Plomp et al. 2016). Traditionally, managers were responsible for the job design process (Oldham \& Fried 2016); however, it is now acknowledged that employees themselves may alter their job boundaries. This ensures that their jobs are congruent with their preferences (Tims \& Bakker 2010). Hence, job crafting serves an aspirational purpose for employees by allowing them to derive meaning from their work (Berg, Dutton \& Wrzesniewski 2010).

Employees have also witnessed the benefits of altering the design of their work by proactively making changes to the demands of their jobs, as well as to resources available in their work (Demerouti 2014; Tims, Bakker \& Derks 2013). Such changes and redesign of one's own work are referred to as job crafting, which is characterised as a self-initiated behaviour. These behaviours should not be considered as independent from the organisational context, as there is a likelihood that some circumstances may warrant more proactive behaviours than others (Parker, Williams \& Turner 2006; Van Wingerden \& Poell 2017). According to Parker and Collins (2010), proactive behaviours start when individuals begin taking a future-centred perspective and take the initiative to make changes happen. Studies have shown that engaging in job crafting enables employees to redesign their tasks or relationships that make up the job to ensure their job remains challenging, motivating and healthy (see Demerouti 2015; Wrzesniewski \& Dutton 2001). Job crafting is a continuous process and increases the fit between the person and the organisation (Berg, Wrzesniewski \& Dutton 2010).

Demerouti, Bakker and Halbesleben (2015) argued that employees are able to make incremental adjustments to their work environment (a view supported by Petrou et al. 2012) by engaging in job crafting, as this fosters work engagement and results in employees finding meaning in their work (Demerouti, Bakker \& Gevers 2015; Gordon et al. 2018; Rudolph et al. 2017; Tims, Bakker, \& Derks 2012).

\section{Job crafting theory}

The theory on job crafting is considered relatively new (Berg, Dutton \& Wrzesniewski 2013) and has been advanced by several scholars using the original conceptualisation of Wrzesniewski and Dutton (2001), which was later empirically tested by several researchers (see Berg, Dutton \& Wrzesniewski 2008; Lyons 2008; Slemp \& Vella-Brodrick 2013). This early conceptualisation defines job crafting as 'the physical and cognitive changes individuals make in the task or relational boundaries of their work' (Wrzesniewski \& Dutton 2001:179).

Two distinct perspectives of job crafting exist and are applied in research, namely, that of Wrzesniewski and Dutton (2001; relational, task and cognitive crafting) and that of Tims et al. (2012; job demands-resources [JD-R]). The first conceptualisation asserts that employees actively make changes to the boundaries of their job to change the meaning of their work and their work identity; in doing so, employees 
may actively partake in any or all forms of relational, cognitive or task crafting (Wrzesniewski \& Dutton 2001). Studies have been built upon this conceptualisation, and it has been noted that employees engage in job crafting by initiating changes to the cognitive, physical and social dimensions of their work to fit their interests and values (Slemp \& Vella-Brodrick 2013), and to match their passions and strengths (Berg et al. 2013).

Tims and Bakker (2010) used the JD-R model to provide insights into how individuals craft their jobs and suggested that job crafting can be operationalised by increasing employees' job resources and challenge demands, whilst decreasing their hindrance demands. According to Tims and Bakker (2010), employees initiate changes to seek a more balanced relationship between the job demands they experience and job resources they can harness based on their personal characteristics and motives. From this perspective, Tims et al. (2012) operationalised job crafting through the widely used scale that measures job crafting on four dimensions, namely, (1) increasing social job resources, followed by (2) increasing structural job resources, (3) decreasing hindering job demands and (4) increasing challenging job demands. Job crafting is considered a job redesign strategy aimed at improving resources, increasing meaning and work engagement (Demerouti \& Bakker 2014).

The aforementioned perspectives differ in the way in which the content and aims of crafting are defined. Wrzesniewski and Dutton's (2001) approach focuses on changes towards the task, cognitive and relational boundaries of an individual's job. The conceptualisation of Tims et al. (2012), however, focuses on changes to the job characteristics of an individual's role. In the former conceptualisation, job crafting enhances meaning and work identity (Wrzesniewski \& Dutton 2001) of an employee, whereas the latter (Tims et al. 2012) may be operationalised differently beyond the original conceptualisation.

Job crafting is not a one-time occurrence, and over time, employees will continue to craft their work. Berg et al. (2008) suggested that crafting involves three general stages. Firstly, individuals become motivated to craft their jobs. Subsequently, individuals identify the available crafting opportunities, in which they may engage or more ways to craft their work. This is followed by employing crafting techniques to actively alter their tasks and activities, interactions with others and reframe the perception of their work.

\section{Wrzesniewski and Dutton's perspective of job crafting}

This perspective sheds light on the three different types of crafting in which the existing employees may engage with, namely, cognitive, task and relational crafting. Changes in employees' tasks, relational boundaries and job identities manifest in employees' experiencing an increased significance for their work (Bakker et al. 2014).

Task crafting: Task crafting refers to the way in which an employee alters the number and type of activities in a job
(Slemp \& Vella-Brodrick 2013, 2014; Wrzesniewski \& Dutton 2001). This suggests that employees take initiative and may mould their tasks by changing their work processes, introduce new tasks or take on fewer tasks, change the timing of their tasks, and seek out activities that are congruent with their skills and interests, thereby altering the scope of their tasks and activities (Niessen, Weseler \& Kostova 2016; Slemp \& Vella-Brodrick 2014).

Cognitive crafting: Wrzesniewski and Dutton (2001) asserted that it is imperative to understand the crafting cognitions of individuals in shaping their work. Individuals alter the way in which they perceive their job in order to experience their work as having personal meaning to them (Berg et al. 2013). This type of crafting allows individuals to be self-aware and shows appreciation for the potential value they contribute through their work, as well as establishes how they remain connected with their work (Slemp \& Vella-Brodrick 2013). Cognitive crafting does not involve any physical changes to their job. It is considered as a mental process focused on changing perceptions or a mindset (Berg et al. 2008). Changes to the cognitive boundaries of one's work relate to how they perceive their job (Bakker \& Demerouti 2007; Berg et al. 2013; Tims, Bakker \& Derks 2014).

Relational crafting: Relational crafting entails employees' exercising discretion and making changes to the manner in which they interact with others in their work organisation. Such changes may include building and maintaining relationships with colleagues, avoiding contact with those with whom they do not get along, and selecting those with whom they wish to spend time (Wrzesniewski \& Dutton 2001). This type of crafting may yield supportive and rewarding interactions, and thus, result in a sense of fulfilment and belonging (Vogel, Rodell \& Lynch 2016). Relational crafting may also increase employees' experience of their jobs as meaningful. This type of crafting has the potential to fulfil the employees' need to connect, build and maintain social relationships (Wrzesniewski \& Dutton 2001).

There are various studies that have applied and followed this conceptualisation of job crafting in changing one's meaning and work identity (e.g. Berg et al. 2010; Geldenhuys, Bakker \& Demerouti 2020; Slemp \& Vella-Brodrick 2013; Vogel et al. 2016; Wrzesniewski et al. 2013).

\section{Tims and Bakker's perspective of job crafting}

Building upon the conceptualisation put forward by Wrzesniewski and Dutton (2001), for the sake of studying job-crafting behaviours, Tims and Bakker (2010) expanded on the JD-R model put forward by Demerouti et al. (2001). The JD-R model accounts for job redesign (Bakker \& Demerouti 2014), and distinguishes two overarching job characteristics, namely, job demands and job resources (Bakker \& Demerouti 2014; Tims et al. 2013). Job demands are considered as challenge demands and make reference to facets of the job that require investment of an employee's effort and energy (e.g. workload; LePine, Podsakoff \& LePine 
2005). Job resources help to address job demands and deal with aspects of the job that allow for motivational potential, growth and development (e.g. development and feedback; Bakker 2011). According to Tims et al. (2013), job crafting using the JD-R model consists of four conceptually different dimensions as outlined previously (because of their similarity, increasing social job resources and increasing structural job resources are discussed under one heading).

Increasing social and structural job resources: Job resources have been shown to enhance and influence work engagement (Halbesleben 2010; Petrou, Bakker \& Van den Heuvel 2017), and are associated with positive organisational outcomes (Xanthopoulou et al. 2009). In addition, job resources act as a buffer to the consequences of job demands (Bakker \& Demerouti 2007; Hakanen \& Roodt 2010). Job resources are likely to impact job design. Autonomy is an example of a structural job resource, whilst feedback and social support are social job resources that have the potential to impact social aspects of one's job (Tims et al. 2012).

Increasing challenge job demands: Experiencing challenging job demands is essential for work motivation, as these hold significant implications for both the employee and the organisation by allowing existing employees to further refine and develop their capabilities, thereby growing the potential to achieve challenging goals (LePine et al. 2005). As employees might experience a state of demotivation when they are not able to use their skills, higher levels of job demands hold the potential to increase perceived job demands in a positive manner through the creation of additional barriers or challenges for individuals. Such challenge demands do not deplete an individual's energy and do not have negative work outcomes as they relate to goal achievement and increased work motivation (Cavanaughet al. 2000). Individuals who increase their challenge demands experience their job as stimulating (Harju, Hakanen \& Schaufeli 2016). Examples of challenge demands include time pressure and increased workload (Tims et al. 2012).

Decreasing hindrance job demands: Employees may engage in job crafting to proactively reduce the job demands that they perceive as overwhelming (Schaufeli, Bakker \& Van Rhenen 2009). Prolonged exposure to hindrance job demands leads to burnout, contributing towards a decrease in one's energy and resulting in health impairment (Schaufeli et al. 2009; Tadić, Bakker \& Oerlemans 2015). Hindrance demands are considered as stressful demands and act as barriers to one's learning and personal growth (Tims et al. 2012).

\section{Outcomes of job crafting}

According to Berg et al. (2008), job crafting is not a single occurrence but rather a process, whereby an individual engages in job crafting over a period of time. Encouraging proactive behaviours typically involves the process of job crafting, which is essential for improving employees' work conditions (Demerouti 2014). Proactive employees show an increased performance and enhanced development (Grant,
Parker \& Collins 2009). Central to the concept of job crafting is the notion that employees hold the key to structuring their own job characteristics or tasks at their own volition. Employees who undertake job crafting are shown to create opportunities to be innovative, as job crafting promotes inventive thinking and skills to be utilised for new work processes (Rudolph et al. 2017). Job crafting is acknowledged as a powerful behaviour, in which employees can engage, and is essential for maintaining person-job fit. This provides employees an avenue to confidently craft their job (Tims \& Bakker 2010; Tims et al. 2013).

Job crafting also has the potential to increase meaningfulness (Dhanpat, De Braine \& Geldenhuys 2019; Geldenhuys et al. 2020) and have a positive influence on work satisfaction (Ghitulescu 2007). Job-crafting intervention studies have shown that job crafters enhance their well-being and performance (Gordon et al. 2018; Van Wingerden, Bakker, \& Derks 2017). In addition, studies have shown that job crafting as a positive proactive work strategy has the potential to increase one's performance and produce various organisational benefits (Crawford, LePine \& Rich 2010; Demerouti \& Bakker 2014).

\section{Method}

This study is presented as a conceptual paper in the form of a theoretical, non-empirical study, employing a modelbuilding approach. This research study follows a deductive research approach, aiming to draw links between construct and existing theories in the fields of intrapreneurship and job crafting. A qualitative research approach is, therefore, followed. The study employs a narrative review methodology and critically reviews landmark and emerging theories in the literature in the fields of intrapreneurship, IO and job crafting.

\section{Discussion}

Much emphasis is being placed on the importance of intrapreneurial behaviours (Antončič \& Hisrich 2003; Ireland et al. 2009), and a renewed interest exists in job crafting (Demerouti 2015), offering a promising direction within management sciences. Shifts towards a knowledge and service economy have brought about varying approaches of which individuals should remain cognisant, as they are considered active creators of their jobs (Grant \& Parker 2009; Nielsen et al. 2010). When exploring job crafting through the lens of either Wrzesniewski and Dutton (2001) or Tims et al. (2012), it is imperative to bear in mind the factors that drive employees to craft their work, namely, motivating and inhibiting factors (Demerouti 2014). More so, it is essential to establish intrapreneurial behaviours as an outcome, in the case of this research study. In the changing context of work, job redesign interventions should target such behaviours. According to Arnolds and Venter (2007), job design rewards are considered as important motivators of job performance. It remains essential that communication of job crafting with employees occurs through formal or informal channels, as this is considered central for developing their confidence when engaging in crafting behaviours (Rai 2018). 
Studies on intrapreneurship (see Farrukh et al. 2017; Urban \& Wood 2017) suggest that establishing the scope of intrapreneurship or its underlying dimensions are in conflict with its conditions. According to Schmelter (2010), the circumstances in which intrapreneurship is facilitated act as a foundation towards enhancing organisational practices and increasing rewards to stimulate intrapreneurial behaviour. The theoretical underpinnings of the IO concept, in the form of $\mathrm{EO}$, reinforce the long-held belief that organisational performance and level of entrepreneurship displayed by employees are a product of organisation-wide initiatives aimed at the structural, policy and management level. It is, therefore, assumed that organisational policy, procedure and management of employees drive entrepreneurial behaviours. The IO theory, in line with theories of job crafting, acknowledges the important role that the organisational environment plays, but that at the same time innovative behaviours are ultimately implemented, driven and based on the motivation of the individual employee. Intrapreneurial behaviours, therefore, go further than just policy and structure; they take into account the entrepreneurial characteristics of the employee. This implies that an employee should have both the ability and willingness to act in a manner that supports innovation, risk taking, autonomy, proactiveness and competitive aggressiveness. Although all five dimensions do not necessarily come naturally to every person, job crafting can act as a powerful tool to harness the inherent and learnt skills and traits of an employee. Authors, such as Goosen, De Coning and Smit (2002), aptly captured the role that management plays in encouraging intrapreneurial behaviours. These include provision of capital to employees, adequate goal setting, championing efforts, reward systems, freedom to experiment and communication. However, the research study has shown that management will at times hinder intrapreneurial efforts by reducing freedom, curtailing communication and ceasing to champion efforts if a risk assessment shows high risk (Goosen et al. 2002; Robert \& Weiss 1988). The important role of managerial support has been widely acknowledged, whilst it is much often more explored than the absence of support, in the form of indifference, can also curtail intrapreneurship (MacMillan, Block \& Narashima 1986; Pinchot 1985). Other authors, such as Bolton (2012), Bolton and Lane (2012) and Robinson et al. (1991), have provided a stronger focus on the individual employee, arguing that items, such as risk taking, innovativeness, proactiveness, personal control, self-esteem and having an achievement orientation, positively relate to IO. Schachtebeck (2018) termed these personal element factors of IO in support of achievement of organisational outcomes through intrapreneurial behaviours.

Hisrich and Kearney (2012) stressed that the rapidly changing competitive environment forces organisations to focus on intra-organisational processes that result in employees having the ability to turn opportunities into innovation. In support, Ma, Liu and Karri (2016) stated that the employee is the source of innovation in an organisation, thereby giving credence to the notion that employees possessing necessary abilities, skills and temperament can produce a substantial value for organisations by means of exploitation of opportunities through innovation, provided that the employee's role is supportive of these types of endeavours.

Pressure mounts on organisations to remain adaptable and agile, whilst promoting creativity and problem solving in employees is increasingly important (Williams 2001). Notably, job crafting is one of the ways of promoting such outcomes (Rai 2018). There are widely recognised positive outcomes of job crafting, as outlined in this paper (Tims et al. 2013 , 2015). In the line of job-crafting research, several links have been made that have beneficial outcomes for employees, which include increased job performance (Tims et al. 2012) and effective problem solving (Daniels et al. 2013). Whilst there are varying reasons that employees engage in job crafting, it is essential to promote job crafting for individuals who engage in demanding work situations. Job crafting can be seen as a way for employees to improve their work lives. If enacted appropriately, employees can make valuable contributions to their organisations (Berg et al. 2008).

This research study encourages the need for intrapreneurial behaviours and implies that the outcomes of such behaviours are essential. Effective proactive interventions should be present in all work areas (eds. Biron, Karanika-Murray \& Copper 2012; Meyers, Van Woerkom \& Bakker 2013). It is vital that organisations be able to establish and understand the role of workplace characteristics to facilitate job-crafting behaviours. According to Tims and Bakker (2010), individual differences amongst employees, such as self-efficacy or a proactive personality, stimulate some employees to craft their jobs more than others. Notably, studies have established that job crafting, when used as a proactive work strategy, holds the potential to increase individual performance, thereby yielding better organisational outcomes (Crawford et al. 2010; Demerouti \& Bakker 2014).

Researchers describe intrapreneurship as proactive workrelated activities of individuals that, as a result, have the potential to turn ideas into organisational success (Moriano et al. 2014). As such, we recommend empirical research studies be conducted in examining the overall effects of job crafting from either Wrzesniewski and Dutton (2001) or Tims and Bakker's (2012) perspective on intrapreneurial behaviour and its anticipated organisational and individual outcomes. This provides insights into understanding how employees who engage in job-crafting behaviours are able to make changes in their job, perform their jobs effectively, and hence, have control over and influence their daily work environment. The scant literature and lack of an existing body of research on the promotion of intrapreneurial behaviours in an organisation have resulted in a lag in the development of an appropriate research instrument and measurements (Slavec \& Drnovsek 2012).

\section{Conclusion}

As job crafting is an emerging field that is rapidly gaining traction, mainly because of a theoretical and practical 
appreciation of its holding valuable benefits for employees and organisations, its connection to sought-after intrapreneurial and entrepreneurial behaviours should not be understated.

From the narrative review, it becomes apparent that intrapreneurial behaviours are not only driven by organisationwide policies and initiatives but also are very personal to the employee. This study, therefore, aims at bringing an increased appreciation to individual-level traits of intrapreneurs, as well as their needed ability to craft their own jobs in support of innovative outputs and outcomes, thereby yielding positive organisational outcomes, mainly in the form of increased levels of innovation, competitiveness, market standing and ultimately, profitability and sustainability. The development of a model to guide implementation of these intrapreneurial and job-crafting initiatives is severely lacking in practice. This study has some implications for future research, for instance, the need for empirically testing the relationship of variables under study. Furthermore, there is a need to establish ways in which job crafting can promote intrapreneurial behaviours and their implications on organisational outcomes, such as performance with regard to growth and profitability. Jobcrafting interventions are likely to assist in encouraging job crafters and their frequency thereof. Future studies may, therefore, focus on developing and testing such models, which would hold benefits for both SMEs and large corporates alike, as the positive organisational benefits of both intrapreneurship and job crafting have been acknowledged in the existing body of knowledge. Future studies can also focus on the development of a conceptual framework for implementation of IO and jobcrafting initiatives, as well as on the development of an instrument that allows for accurate measurement of the current state of job crafting and IO.

\section{Acknowledgements \\ Competing interests}

The authors declare that they have no financial or personal relationships that may have inappropriately influenced them in writing this article.

\section{Authors' contributions}

N.D. and C.S. both conceptualised, researched and coauthored the article.

\section{Ethical considerations}

This article followed all ethical standards for research without direct contact with human or animal subjects.

\section{Funding information}

This research study received no specific grant from any funding agency in the public, commercial or not-for-profit sectors.

\section{Data availability}

Data sharing is not applicable to this article, as no new data were created or analysed in this study.

\section{Disclaimer}

The views and opinions expressed in this article are those of the authors and do not necessarily reflect the official policy or position of any affiliated agency of the authors.

\section{References}

Aarakit, S.M., 2010, 'Intrapreneurial orientation, social networks and firm performance', Master's dissertation, Makerere University, Kampala.

Aarakit, S.M. \& Kimbugwe, F.K., 2015, 'The relationship between intrapreneuria orientation and firm performance', Global Advanced Research Journal of Social Science 4(1), 6-10. https://doi.org/10.23958/ijssei/vol01-i01/07

Antončič, B., 2003, 'Risk taking in intrapreneurship: Translating the individual level risk aversion into the organizational risk taking', Journal of Enterprising Culture 11(1), $1-23$.

Antončič, B. \& Hisrich, R.D., 2001, 'Intrapreneurship: Construct refinement and crosscultural validation', Journal of Business Venturing 16(5), 495-527. https://doi. org/10.1016/S0883-9026(99)00054-3

Antončič, B. \& Hisrich, R.D., 2003, 'Clarifying the intrapreneurship concept', Journal of Small Business and Enterprise Development 10(1), 7-24. https://doi. org/10.1108/14626000310461187

Antončič, B. \& Hisrich, R.D., 2004, 'Corporate entrepreneurship contingencies and organizational wealth creation', Journal of Management Development 23(6), 518-550. https://doi.org/10.1108/02621710410541114

Antončič, B. \& Scarlat, C., 2005, 'Corporate entrepreneurship and organizational performance: A comparison between Slovenia and Romania', in Proceedings of the 6th International Conference of the Faculty of Management Koper Congress Centre, November 24-26, 2005, Bernardin, 2005, pp. 15-38.

Arnolds, C.A. \& Venter, D.J.L., 2007, 'The strategic importance of motivational rewards for lower-level employees in the manufacturing and retailing industries', SA Journal of Industrial Psychology 33(3), 15-23. https://doi.org/10.4102/sajip.v33i3.390

Avlonitis, G.J. \& Salavou, H.E., 2007, 'Entrepreneurial orientation of SMEs, product innovativeness and performance', Journal of Business Research 60(5), 566-575. https://doi.org/10.4102/sajip.v33i3.390

Azami, S., 2013, 'Intrapreneurship - "An Exigent employment"', International Journal of Scientific \& Technology Research 2(4), 194-198.

Badenhorst-Weiss, J.A. \& Cilliers, J.O., 2014, 'Competitive advantage of independent small business in Soweto', Southern African Business Review 18(3), 1-21. https:// doi.org/10.25159/1998-8125/5683

Bakker, A.B., 2011, 'An evidence-based model of work engagement', Current Directions in Psychological Science 20(4), 265-269. https://doi.org/10.1177/ 0963721411414534

Bakker, A.B. \& Demerouti, E., 2007, 'The job demands-Resources model: State of the art', Journal of Managerial Psychology 22(3), 309-328. https://doi. org/10.1108/02683940710733115

Bakker, A.B. \& Demerouti, E., 2014, 'Job demands-resources theory', in P.Y. Chen \& C.L. Cooper (eds.), Work and wellbeing: Wellbeing: A complete reference guide, pp. 1-28, Wiley-Blackwell, Chichester.

Bakker, A.B., Ficapal-Cusí, P., Torrent-Sellens, J., Boada-Grau, J. \& Hontangas-Beltrán P.M., 2018, 'The Spanish version of the job crafting scale', Psicothema 30(1), 136-142. https://doi.org/10.1037/t74717-000

Belousova, O., Gailly, B. \& Basso, B., 2010, 'A conceptual model of corporate entrepreneurial behaviour', in Proceedings of the 2010 Babson College Entrepreneurship Research Conference, 9-13 June 2010, Lausanne, 2008, pp. 1-32.

Berg, J.M., Dutton, J.E. \& Wrzesniewski, A., 2008, What is job crafting and why does it matter?, viewed 11 August 2020, from https://positiveorgs.bus.umich.edu/wpcontent/uploads/What-is-Job-Crafting-and-Why-Does-it-Matter1.pdf

Berg, J.M., Dutton, J.E. \& Wrzesniewski, A., 2013, 'Job crafting and meaningful work', Purpose and Meaning in the Workplace 81, 104. https://doi.org/10.1037/14183-005

Berg, J.M., Wrzesniewski, A. \& Dutton, J.E., 2010, 'Perceiving and responding to challenges in job crafting at different ranks: When proactivity requires adaptivity', Journal of Organizational Behavior 31(2-3), 158-186. https://psycnet.apa.org/ doi/10.1002/job.645

Biron, C., Karanika-Murray, M. \& Copper, C.L. (eds.), 2012, Improving organizational interventions for stress and well-being: Addressing process and context, Routledge, London.

Blundel, R. \& Lockett, N., 2011, Exploring entrepreneurship: Practices and perspectives, Oxford University Press, New York, NY.

Boehnlein, P. \& Baum, M., 2020, 'Does job crafting always lead to employee well-being and performance? Meta-analytical evidence on the moderating role of societal culture', The International Journal of Human Resource Management 1-39. https://doi.org/10.1080/09585192.2020.1737177

Bolton, D.L., 2012, 'Individual entrepreneurship orientation: Further investigation of a measurement instrument', Academy of Entrepreneurship Journal 18(1), 91-98.

Bolton, D.L. \& Lane, M.D., 2012, 'Individual entrepreneurial orientation: Development of a measurement instrument', Education + Training 54(2/3), 219-233. https:// doi.org/10.1108/00400911211210314

Camelo-Ordaz, C., Fernández-Alles, M., Ruiz-Navarro, J. \& Sousa-Ginel, E., 2011, 'The intrapreneur and innovation in creative firms', International Small Business Journal 30(5), 513-535. https://doi.org/10.1177/0266242610385396 
Cavanaugh, M.A., Boswell, W.R., Roehling, M.V., \& Boudreau, J.W., 2000, 'An empirical examination of self-reported work stress among US managers', Journal of Applied Psychology 85(1), 65-74. https://doi.org/10.1037/0021-9010.85.1.65

Covin, J.G. \& Lumpkin, G.T., 2011, 'Entrepreneurial orientation theory and research: Reflections on a needed construct', Entrepreneurship Theory and Practice 35(5), 855-872. https://doi.org/10.1111/j.1540-6520.2011.00482.x

Covin, J.G. \& Miles, M.P., 1999, 'Corporate entrepreneurship and the pursuit of competitive advantage', Entrepreneurship Theory and Practice 23(3), 47-63. https://doi.org/10.1177/104225879902300304

Covin, J.G. \& Slevin, D.P., 1986, 'The development and testing of an organizationallevel entrepreneurship scale', in R. Ronstadt, A. Hornaday, R. Peterson \& K.H. Vesper (eds.), Frontiers of entrepreneurship research, pp 628-639, Babson College, Wellesley.

Covin, J.G. \& Slevin, D.P., 1989, 'Strategic management of small firms in hostile and benign environments', Strategic Management Journal 10(1), 75-87. https://doi. org/10.1002/smj.4250100107

Covin, J.G. \& Slevin, D.P., 1991, 'A conceptual model of entrepreneurship as firm behaviour', Entrepreneurship Theory and Practice 16(1), 7-26. https://doi. org/10.1177/104225879101600102

Covin, J.G. \& Slevin, D.P., 1997, 'High growth transitions: Theoretical perspectives and suggested directions', In D.L. Sexton \& R.W. Smilor (eds.), Entrepreneurship 2000, pp. 99-126, Upstart Publishing, Chicago.

Crawford, E.R., LePine, J.A. \& Rich, B.L., 2010, 'Linking job demands and resources to employee engagement and burnout: A theoretical extension and meta-analytic test', Journal of Applied Psychology 95(5), 834-848. https://doi.org/10.1037/ test', Journal

Daniels, K., Beesley, N., Wimalasiri, V. \& Cheyne, A., 2013, 'Problem solving and wellbeing: Exploring the instrumental role of job control and social support', Journa of Management 39(4), 1016-1043. https://doi.org/10.1177/0149206311430262

Demerouti, E., 2014, 'Design your own job through job crafting', European Psychologist 19(4), 237-247. https://doi.org/10.1027/1016-9040/a000188

Demerouti, E., 2015, 'Strategies used by individuals to prevent burnout', European Journal of Clinical Investigation 45(10), 1106-1112. https://doi.org/10.1111/ eci.12494

Demerouti, E. \& Bakker, A.B., 2014, 'Job crafting' In M.C.W. Peeters, J. de Jonge, \& T.W. Taris (eds.), An introduction to contemporary work psychology, pp. 414-433, John Wiley \& Sons, Chichester

Demerouti, E., Bakker, A.B. \& Gevers, J.M., 2015, 'Job crafting and extra-role behavior: The role of work engagement and flourishing', Journal of Vocational Behavior 91, 87-96. https://doi.org/10.1016/j.jvb.2015.09.001

Demerouti, E., Bakker, A.B. \& Halbesleben, J.R., 2015, 'Productive and counterproductive job crafting: A daily diary study', Journal of Occupational counterproductive job crafting: A daily diary study', Journal of O
Health Psychology 20(4), 457-469. https://doi.org/10.1037/a0039002

Demerouti, E., Bakker, A.B., Nachreiner, F. \& Schaufeli, W.B., 2001, 'The job demands - Resources model of burnout', Journal of Applied Psychology 86(3), 499-512. https://doi.org/10.1037/0021-9010.86.3.499

Dess, G.G. \& Lumpkin, G.T., 2005, 'The role of entrepreneurial orientation in stimulating effective corporate entrepreneurship', The Academy of Managemen Executive, 19(1), 147-156.

Dhanpat, N., De Braine, R.T. \& Geldenhuys, M., 2019, 'Weekly job crafting and weekly meaningful work. A diary study', Paper presented at the European Academy of Management (2019, July). Lisbon, Portugal, pp. 1-27.

Dhanpat, N. \& Schachtebeck, C., 2019, 'Corporate entrepreneurship: It's a matter of engagement', in Proceeding of the 14th International Business Conference, 22-26 September 2019, Hermanus, South Africa, pp. 439-449.

Drotskie, A. \& Okanga, B., 2016, 'Managing customer-supplier relationship between big businesses and SMEs in South Africa', Journal of Contemporary Management $13(1), 190-221$.

Farrukh, M., Chong, W.Y., Mansori, S. \& Ramzani, S.R., 2017, 'Intrapreneurial behaviour: The role of organizational commitment', World Journal of Entrepreneurship, Management and Sustainable Development 13(3), 1-27. Entrepreneurship, Management and Sustainable
https://doi.org/10.1108/WJEMSD-03-2017-0016

Geldenhuys, M., Bakker, A.B. \& Demerouti, E., 2020, 'How task, relational and cognitive crafting relate to job performance: A weekly diary study on the role of meaningfulness', European Journal of Work and Organizational Psychology 30(1) 83-94. https://doi.org/10.1080/1359432X.2020.1825378

Ghitulescu, B.E., 2007, 'Shaping tasks and relationships at work: Examining the antecedents and consequences of employee job crafting', Doctoral dissertation, University of Pittsburgh, Pittsburgh, Pennsylvania.

Goosen, C.J., De Coning, T.J. \& Smit, E.M., 2002, 'Corporate entrepreneurship and financial performance: The role of management', South African Journal of Business Management 33(4), 21-27. https://doi.org/10.4102/sajbm.v33i4.708

Gordon, H.J., Demerouti, E., Le Blanc, P.M., Bakker, A.B., Bipp, T. \& Verhagen, M.A. 2018 , 'Individual job redesign: Job crafting interventions in healthcare', Journal of Vocational Behavior 104, 98-114. https://doi.org/10.1016/j.jvb.2017.07.002

Grant, A.M. \& Parker, S.K., 2009, '7 redesigning work design theories: The rise of relational and proactive perspectives', The Academy of Management Annals 3(1) 317-375. https://doi.org/10.5465/19416520903047327

Grant, A.M., Parker, S. \& Collins, C., 2009, 'Getting credit for proactive behavior: Supervisor reactions depend on what you value and how you feel', Personnel Psychology 62(1), 31-55. https://doi.org/10.1111/j.1744-6570.2008.01128.x

Groenewald, D. \& Van Vuuren, J.J., 2011, 'Conducting a corporate entrepreneurial health audit in South African short-term insurance businesses', Journal of Contemporary Management 8(1), 1-33.
Griffith, D.A., Noble, S.M. \& Qimei, C., 2006, 'The performance implications of intrapreneurial proclivity: A dynamic capabilities approach', Journal of Retailing intrapreneurial proclivity: A dynamic capabilities approach',
82(1), 51-62. https://doi.org/10.1016/j.jretai.2005.11.007

Hakanen, J.J. \& Roodt, G., 2010, 'Using the job demands-resources model to predict work engagement: Analysing the conceptual model', in A.B. Bakker \& M.P. Leiter (eds.), Work engagement: A handbook of essential theory and research, pp. 85-101, Psychology Press, New York, NY.

Halbesleben, J.R., 2010, 'A meta-analysis of work engagement: Relationships with burnout, demands, resources, and consequences', In A.B. Bakker \& M.P. Leiter (eds.), Work Engagement: A Handbook of Essential Theory and Research, Vol. 8, pp. 102-117, Psychology Press, New York.

Harju, L.K., Hakanen, J.J. \& Schaufeli, W.B., 2016. 'Can job crafting reduce job boredom and increase work engagement? A three-year cross-lagged panel study', Journa of Vocational Behavior 95, 11-20. https://doi.org/10.1016/j.jvb.2016.07.001

Hisrich, R. \& Kearney, C., 2012, Corporate entrepreneurship: How to create a thriving entrepreneurial spirit throughout your company, McGraw-Hill, New York, NY.

Ireland, R.D., Covin, J.G. \& Kuratko, D.F., 2009, 'Conceptualizing corporate entrepreneurship strategy', Entrepreneurship Theory and Practice 33(1), 19-46. https://doi.org/10.1111/j.1540-6520.2008.00279.x

Jacobs, H. \& Kruger, S., 2001, 'Establishing an intrapreneurial orientation as strategy: A framework for implementation', Acta Commercii 1(1), 1-11. https://doi. org/10.4102/ac.v1i1.1

Kelly, D., 2011, 'Sustainable corporate entrepreneurship: Evolving and connecting with the organization', Business Horizons 54(1), 73-83. http://dx.doi. org/10.1016/j.bushor.2010.09.003

Knight, G.A., 1997, 'Cross-cultural reliability and validity of a scale to measure firm entrepreneurial orientation', Journal of Business Venturing 12(3), 213-225. https://doi.org/10.1016/S0883-9026(96)00065-1

Kocjančič, J. \& Bojnec, S., 2013, 'Intrapreneurship, competition and company efficiency', Managing Global Transitions 11(2), 161-179.

Kollmann, T., Christofor, J. \& Kuckertz, A., 2007, 'Explaining individual entrepreneurial orientation: Conceptualisation of a cross-cultural research framework', International Journal of Entrepreneurship and Small Business 4(3), 325-340. https://doi.org/10.1504/IJESB.2007.013255

LePine, J.A., Podsakoff, N.P. \& LePine, M.A., 2005, 'A meta-analytic test of the challenge stressor-Hindrance stressor framework: An explanation for inconsistent relationships among stressors and performance', Academy of Management Journal 48(5), 764-775. https://doi.org/10.5465/amj.2005.18803921

Li, Y., Huang, J. \& Tsai, M., 2009, 'Entrepreneurial orientation and firm performance: The role of knowledge creation process', Industrial Marketing Management 38(4), The role of knowledge creation process', Industrial Marketing Mar

Lumpkin, G.T. \& Dess, G.G., 1996, 'Clarifying the entrepreneurial orientation construct and linking it to performance', Academy of Management Review 21(1), 135-172. https://doi.org/10.5465/ame.2005.15841975

Lumpkin, G.T. \& Dess, G.G., 2005, 'The role of entrepreneurial orientation in stimulating effective corporate entrepreneurship', The Academy of Management Executive 19(1), 147-156. https://doi.org/10.5465/ame.2005.15841975

Lyon, D.W., Lumpkin, G.T. \& Dess, G.G., 2000, ‘Enhancing entrepreneuria orientation research: Operationalizing and measuring a key strategic decisionmaking process', Journal of Management 26(5), 1055-1085. https://doi. org/10.1177/014920630002600503

Lyons, P., 2008, 'The crafting of jobs and individual differences', Journal of Business and Psychology 23(1-2), 25-36. https://doi.org/10.1007/s10869-008-9080-2

Ma, H., Liu, T.Q. \& Karri, R., 2016, 'Internal corporate venturing: Intrapreneurs, institutions and initiatives', Organizational Dynamics 45(2), 114-123. https://doi. org/10.1016/j.orgdyn.2016.02.005

MacMillan, I.C., Block, Z. \& Narashima. P.N.S., 1986, 'Corporate venturing: Alternatives, obstacles encountered and experience effects', Journal of Business Venturing 1(2), 177-191. https://doi.org/10.1016/0883-9026(86)90013-3

Mafini, C., Pooe, D.R.I. \& Loury-Okoumba, V.W., 2016, 'Interrogating antecedents to SME supplier performance in a developing country', Southern African Business Review 20, 259-285. https://doi.org/10.25159/1998-8125/6053

Matsuno, K., Mentzer, J.T. \& Özsomer, A., 2002, 'The effects of entrepreneurial proclivity and market orientation on business performance', Journal of Marketing 66(3), 18-33. https://doi.org/10.1509/jmkg.66.3.18.18507

Meyers, M.C., Van Woerkom, M. \& Bakker, A.B., 2013, 'The added value of the positive: A literature review of positive psychology interventions in organizations', European Journal of Work and Organizational Psychology 22(5), 618-632. https:// doi.org/10.1080/1359432X.2012.694689

Miller, D., 1983, 'The correlates of entrepreneurship in three types of firms', Management Science 29(7), 770-791. https://doi.org/10.1287/mnsc.29.7.770

Mishra, C.S., 2017, Entrepreneurial orientation. In creating and sustaining competitive advantage, Springer, Palgrave, London, UK.

Moriano, J.A., Molero, F., Topa, G. \& Mangin, J.P.L., 2014. 'The influence of transformational leadership and organizational identification on intrapreneurship' International Entrepreneurship and Management Journal 10(1), 103-119. https:// International Entrepreneurship and
doi.org/10.1007/s11365-011-0196-x

Morris, H.M. \& Kuratko, D.F., 2002, Corporate entrepreneurship, Thomson SouthWestern, Ohio.

Morris, H.M., Kuratko, D.F. \& Covin, J.G., 2008, Corporate entrepreneurship \& innovation, Thomson South-Western, Ohio.

Mxunyelwa, S. \& Vallabh, D., 2017, 'Skills as impediment to small and medium tourism enterprises (SMTEs), Eastern Cape, South Africa', African Journal of Hospitality, Tourism and Leisure 6(4), 1-8. 
Neneh, N.B. \& Van Zyl, J.H., 2014, 'Growth intention and its impact on business growth amongst SMEs in South Africa', Mediterranean Journal of Social Sciences 5(20) 172-183. https://doi.org/10.5901/mjss.2014.v5n20p172

Nielsen, K., Randall, R., Holten, A.L. \& González, E.R., 2010, 'Conducting organizationallevel occupational health interventions: What works?', Work \& Stress 24(3) 234-259. https://doi.org/10.1080/02678373.2010.515393

Niessen, C., Weseler, D. \& Kostova, P., 2016, 'When and why do individuals craft their jobs? The role of individual motivation and work characteristics for job crafting, Human Relations 69(6), 1287-1313. https://doi.org/10.1177/0018726715610642

Oldham, G.R. \& Fried, Y., 2016, 'Job design research and theory: Past, present and future', Organizational Behavior and Human Decision Processes 136, 20-35. https://doi.org/10.1016/j.obhdp.2016.05.002

Oldham, G.R. \& Hackman, J.R., 2010, 'Not what it was and not what it will be: The future of job design research', Journal of organizational behavior, 31(2-3), 463-479. https://doi.org/10.1002/job.678

Okanga, B. \& Drotskie, A., 2016, 'Managing the early stages of SME's sustainability and growth', Journal of Contemporary Management 13(1), 621-650.

Parker, S.K. \& Collins, C.G., 2010, 'Taking stock: Integrating and differentiating multiple proactive behaviors', Journal of Management 36(3), 633-662. https://doi. org/10.1177/0149206308321554

Parker, S.K., Williams, H.M. \& Turner, N., 2006, 'Modeling the antecedents of proactive behavior at work', Journal of Applied Psychology 91(3), 636-652. https://doi. org/10.1177/0149206308321554

Petrou, P., Bakker, A.B. \& Van den Heuvel, M., 2017, 'Weekly job crafting and leisure crafting: Implications for meaning-making and work engagement', Journal of Occupational and Organizational Psychology 90(2), 129-152. https://do . org/10.1111/joop.12160

Petrou, P., Demerouti, E., Peeters, M.C., Schaufeli, W.B. \& Hetland, J., 2012, 'Crafting a job on a daily basis: Contextual correlates and the link to work engagement' Journal of Organizational Behavior 33(8), 1120-1141. https://doi.org/10.1002/ job.1783

Pinchot, G., 1985, Intrapreneuring, Harper \& Row, New York, NY.

Plomp, J., Tims, M., Akkermans, J., Khapova, S.N., Jansen, P.G. \& Bakker, A.B., 2016, 'Career competencies and job crafting', Career Development International 21(6), 587-602. https://doi.org/10.1108/CDI-08-2016-0145

Quaye, D., Acheampong, G. \& Asiedu, M., 2015, 'Gender differences in entrepreneurial orientation: Evidence from Ghana', European Journal of Business and Management 7(12), 128-139.

Rahayu, R. \& Day, J., 2015, 'Determinant factors of e-commerce adoption by SMEs in developing country: Evidence from Indonesia', Procedia - Social and Behavioral Sciences 195, 142-150. https://doi.org/10.1016/j.sbspro.2015.06.423

Rai, A., 2018, 'Job crafting intervention: Fostering individual job redesign for sustainable organisation', Industrial and Commercial Training 50(4), 200-208. https://doi.org/10.1108/ICT-11-2017-0089

Rauch, A., Wiklund, J., Lumpkin, G.T. \& Frese, M., 2009, 'Entrepreneurial orientation and business performance: An assessment of past research and suggestions fo the future', Entrepreneurship Theory and Practice 33(3), 761-787. https://doi. org/10.1111/j.1540-6520.2009.00308.x

Robert, M. \& Weiss, A., 1988, The innovation formula: How organisations turn change into opportunity, Ballinger, Cambridge.

Robinson, P.B., Stimpson, D.V., Huefner, J.C. \& Hunt, H.K., 1991, 'An attitude approach to the prediction of entrepreneurship', Entrepreneurship Theory \& Practice 15(4), 13-31. https://doi.org/10.1177/104225879101500405

Rudolph, C.W., Katz, I.M., Lavigne, K.N. \& Zacher, H., 2017, 'Job crafting: A metaanalysis of relationships with individual differences, job characteristics, and work outcomes', Journal of Vocational Behavior 102, 112-138. https://doi. org/10.1016/j.jvb.2017.05.008

Schachtebeck, C., 2018, 'Individual-level intrapreneurial orientation and organisational growth in small and medium enterprises', Doctoral thesis, University of Johannesburg, Johannesburg.

Schaufeli, W.B., Bakker, A.B. \& Van Rhenen, W., 2009. 'How changes in job demands and resources predict burnout, work engagement, and sickness absenteeism', and resources predict burnout, work engagement, and sickness absenteeism, Occupational and Organizational Psychology and Behavior 30(7), 893-917. Occupational and Organization
https://doi.org/10.1002/job.595

Schmelter, R., Mauer, R., Borsch, C. \& Brettel, M., 2010, 'Boosting corporate entrepreneurship through HRM practices: Evidence from German SMEs', Human Resources Management 49(4), 715-741. https://doi.org/10.1002/hrm.20366

Schulte, P.A. \& Vainio, H., 2010, 'Well-being at work - Overview and perspective', Scandinavian Journal of Work, Environment \& Health 36(5), 422-429. https://doi. org/10.5271/sjweh.3076

Slavec, A. \& Drnovsek, M., 2012, 'A perspective on scale development in entrepreneurship research', Economic and Business Review 14(1), 39-62.

Slemp, G.R. \& Vella-Brodrick, D.A., 2013, 'The job crafting questionnaire: A new scale to measure the extent to which employees engage in job crafting', International Journal of wellbeing 3(2), 126-146.

Slemp, G.R. \& Vella-Brodrick, D.A., 2014, 'Optimising employee mental health: The relationship between intrinsic need satisfaction, job crafting, and employee wellbeing', Journal of Happiness Studies 15(4), 957-977. https://doi.org/10.1007/ s10902-013-9458-3
Stewart, J.K., 2009, 'An investigation of an intrapreneurial orientation among employees in service organisations', Doctoral thesis, Ohio State University, Columbus.

Strydom, J., 2013, Principles of business management, Oxford Publishing, Cape Town.

Tadić, M., Bakker, A.B. \& Oerlemans, W.G., 2015. 'Challenge versus hindrance job demands and well-being: A diary study on the moderating role of job resources' Journal of Occupational and Organizational Psychology 88(4), 702-725. https:// doi.org/10.1111/joop.12094

Teles, D. \& Schachtebeck, C., 2019, 'Entrepreneurial orientation in South African social enterprises', Entrepreneurial Business and Economics Review 7(3), 83-97. https:// doi.org/10.15678/EBER.2019.070305

Tims, M. \& Bakker, A.B., 2010, 'Job crafting: Towards a new model of individual job redesign', SA Journal of Industrial Psychology 36(2), 1-9. https://doi.org/10.4102/ sajip.v36i2.841

Tims, M., Bakker, A.B. \& Derks, D., 2012, 'Development and validation of the job crafting scale', Journal of Vocational Behavior 80(1), 173-186. https://doi. org/10.1016/j.jvb.2011.05.009

Tims, M., Bakker, A.B. \& Derks, D., 2013, 'The impact of job crafting on job demands, job resources, and well-being', Journal of Occupational Health Psychology 18(2), 230-240. https://doi.org/10.1037/a0032141

Tims, M., Bakker, A.B. \& Derks, D., 2014, 'Daily job crafting and the self-efficacyperformance relationship', Journal of Managerial Psychology 29(5), 490-507. https://doi.org/10.1108/JMP-05-2012-0148

Tims, M., Bakker, A.B. \& Derks, D., 2015, 'Job crafting and job performance: A longitudinal study', European Journal of Work and Organizational Psychology 24(6), 914-928. https://doi.org/10.1080/1359432X.2014.969245

Tims, M., Bakker, A.B., Derks, D. \& Van Rhenen, W., 2013, 'Job crafting at the team and individual level: Implications for work engagement and performance', Group \& Organization Management 38(4), 427-454. https://doi. org/10.1177/1059601113492421

Urban, B., 2011, 'Elements of organizational architecture conducive to corporate entrepreneurship strategy', Journal of Contemporary Management 8(1), 429-452.

Urban, B., 2012, 'The effect of pro-entrepreneurship architecture on organisational outcomes', Journal of Business Economics and Management 13(3), 518-545. https://doi.org/10.3846/16111699.2011.620153

Urban, B. \& Wood, E., 2017, 'The innovation firm as corporate entrepreneurship', European Journal of Innovation Management 20(4), 534-556. https://doi. org/10.1108/EJIM-10-2016-0100

Van Aardt, I. \& Bezuidenhout, S., 2017, Entrepreneurship \& new venture management, Oxford University Press, Cape Town.

Van Niekerk, C., 2014, 'Ethics or survival: The meaning of good and bad in small South African businesses', International Retail \& Marketing Review 9(1), 79-89.

Van Wingerden, J. \& Poell, R.F., 2017, 'Employees' perceived opportunities to craft and in-role performance: The mediating role of job crafting and work engagement', Frontiers in Psychology 8(1876), 1-9. https://doi.org/10.3389/fpsyg.2017.01876

Van Wingerden, J., Derks, D. \& Bakker, A.B., 2017, 'The impact of personal resources and job crafting interventions on work engagement and performance', Human Resource Management 56(1), 51-67. https://psycnet.apa.org/doi/10.1002/ hrm.21758

Van Wyk, R. \& Adonisi, M., 2012, 'Antecedents of corporate entrepreneurship', South African Journal of Business Management 43(3), 65-78. https://doi.org/10.4102/ sajbm.v43i3.475

Vogel, R.M., Rodell, J.B. \& Lynch, J.W., 2016, 'Engaged and productive misfits: How job crafting and leisure activity mitigate the negative effects of value incongruence', Academy of Management Journal 59(5), 1561-1584. https://doi.org/10.5465/ amj.2014.0850

Weseler, D. \& Niessen, C., 2016, 'How job crafting relates to task performance', Journal of Managerial Psychology 31(3), 672-685. https://doi.org/10.1108/JMP-09-2014of $M$.

Williams, S., 2001, 'Increasing employees' creativity by training their managers', Industrial and Commercial Training 33(2), 63-68. https://doi. org/10.1108/00197850110385642

Wrzesniewski, A. \& Dutton, J.E., 2001, 'Crafting a job: Revisioning employees as active crafters of their work', Academy of Management Review 26(2), 179-201. https:// doi.org/10.5465/amr.2001.4378011

Wrzesniewski, A., LoBuglio, N., Dutton, J.E. \& Berg, J.M., 2013, 'Job crafting and cultivating positive meaning and identity in work', in A.B. Bakker (ed.), Advances in positive organizational psychology, pp. 281-302, Emerald, London.

Xanthopoulou, D., Bakker, A.B., Demerouti, E. \& Schaufeli, W.B., 2009. 'Reciprocal relationships between job resources, personal resources, and work engagement',
Journal of Vocational Behavior 74(3), 235-244. https://doi.org/10.1016/j. Journal of Vocatic

Zahra, S.A., 1991, 'Predictors and financial outcomes of corporate entrepreneurship: An exploratory study', Journal of Business Venturing 6(4), 259-285. https://doi. An exploratory study', Journal of Busine
org/10.1016/0883-9026(91)90019-A

Zahra, S.A., 1993, 'Environment, corporate entrepreneurship, and financial performance: A taxonomic approach', Journal of Business Venturing 8(4), 319340. https://doi.org/10.1016/0883-9026(93)90003-N

Zahra, S.A. \& Covin, J.G., 1995, 'Contextual influences on the corporate entrepreneurship-performance relationship: A longitudinal analysis', Journal of Business Venturing 10(1), 45-58. https://doi.org/10.1016/0883-9026(94)00004-E 